\title{
Bureaucratic Tax-Seeking: The Danish Waste Tax1
}

\author{
Presented at the Public Choice Workshop II (December 1, 2000), Aarhus University
}

Henrik Christoffersen, hc@akf.dk, http://www.akf.dk/cv/hc.htm

Research Director, AKF, Institute of Local Government Studies

Nyropsgade 37

1602 København C

Denmark

Gert Tinggaard Svendsen, gts@asb.dk, http://www.hha.dk/eok/nat/staff/gts form.htm

Associate Professor, Department of Economics

The Aarhus School of Business

Fuglesangs Allé 20

8210 Aarhus V

Denmark

\section{Summary:}

Two main results in traditional tax theory states the following. First, general taxes minimize the welfare loss from changed relative prices. Second, because the total public budget tends to exceed the optimal size, a leader (here named 'troop leader') is needed in the budget process to prevent over-taxation. Nevertheless, differentiated taxes initiated by individual ministries generate a still larger proportion of total tax revenue, in particular under cover of taxing externalities such as environmental pollution. We suggest that this situation leads to over-taxation for two reasons. First, the absence of a strong and fully informed troop leader prevents rational coordination of collective action. Second, budget maximization leads to overwhelming fiscal pressure because bureaucracies are competing about resources just like fishermen or hunters (here named 'bureaucratic tax-seeking'). Taxing citizens or firms is like harvesting rents from a natural resource and therefore we apply a common-pool resource model. Because bureaucracies compete about maximizing their share of tax payers ' money, this leads to over-taxation and an irrational outcome for both bureaucrats and society. These suggestions are strongly confirmed by the case of the Danish waste tax. Thus, we recommend that bureaucratic institutions should coordinate their tax-seeking efforts to maximize budgets in the long run and that the ministries that collect green tax revenues should not be allowed to control these revenues. Such a budget maximization opportunity would kick off a new self-destructive fiscal race among competing tax-seeking bureaucracies.

JEL-codes: $\mathrm{H} 0-\mathrm{H} 4, \mathrm{Q} 0$.

Key words: bureaucratic tax-seeking, troop leader, common-pool resource model, green taxation, waste tax.

1 Several ideas in this paper are due to Martin Paldam. 


\section{Introduction}

Traditional tax theory states for an economy with exclusively pure private market goods and pure public goods that except for a few cases of very limited scope, taxes used in practice violate the Pareto optimum conditions in an economy without externalities and hence impede an efficient allocation of resources. ${ }^{2}$ Taxation is then in practice - at best - a question of second best solutions. Modern economies contain a variety of mixed goods characterized by negative externalities in the production or in the consumption. Green taxation can ideally neutralize the loss of welfare from such negative externalities. As suggested by Pigou (1920), politicians should control pollution by imposing a uniform tax on the externality following harmful emissions. At the same time green taxation makes the lowering of other distortive taxes possible. In this way, green taxation may provide a double dividend by establishing the collective good of environmental improvement (at least cost) and by lowering other distortive taxes (see Daugbjerg and Svendsen, 2001).

This ongoing restructuring of the tax revenues can therefore eventually contribute to increasing the social efficiency in modern economies recognizing still stronger negative externalities and mobilizing still stronger political capacity to optimizing social efficiency. Green taxes seem in principle to be good taxes. The insight from empirical welfare economics, that green taxation does not generally counterbalance negative externalities in the economy, brings us to introduce disciplines from public choice in search of how to explain the lack of social efficiency.

In spite of the fact, that green taxes are used more and more extensively in Western Europe, policy makers do not follow the advice of environmental economists when designing green taxation. For example, a review of green tax schemes applied in OECD countries clearly shows that economic efficiency has not been the driving force behind the politics of green taxation (ibid.). In general, the level of green taxation in Europe is set too low to have the desired effect on environmental behavior. Thus, Howe (1994) and Daugbjerg and Svendsen, 2001) concludes that the effect of green taxation is fiscal rather than environmental.

\footnotetext{
${ }^{2}$ Bohm (1987).
} 
The fiscal effect from green taxation is shown in Figure 1 below. Here, the graph shows total revenues from green taxation in per cent of total tax revenues in 26 OECD Member countries (for each of the years 1994-1997). The averages included on the right side of the graphs amount to roughly $7 \%$.

Figure 1: Revenues from environmentally related taxes in per cent of total tax revenues, 1994-97.

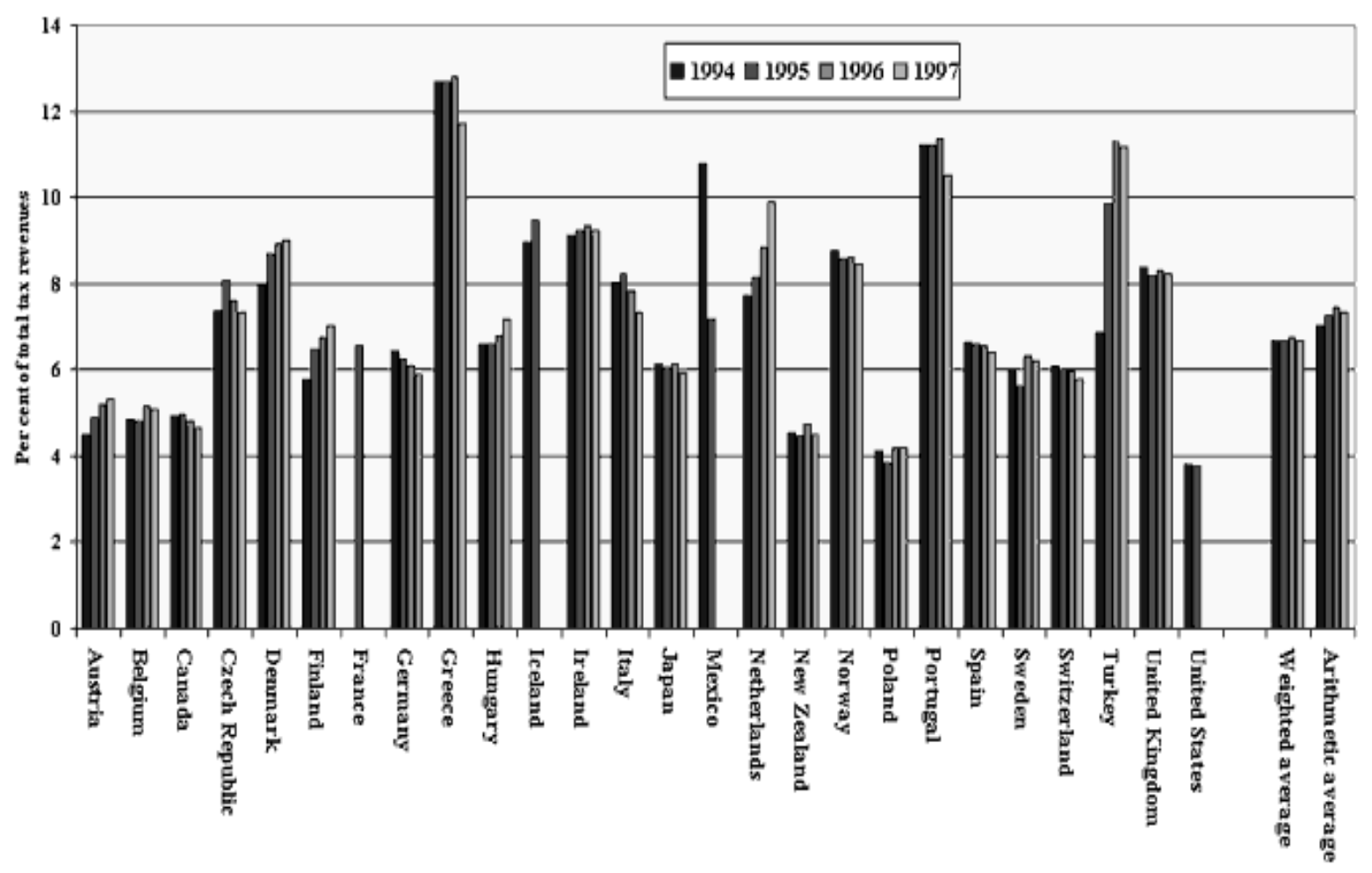

Source: OECD (2000). 
Why does this fiscal pressure from green taxation occur? We will try to answer this question in two steps. First, in Section 2, we undertake a general theoretical analysis building on a 'troop leader model' (based on Von Hagen and Harden, 1995) and a 'common-pool resource model' (based on Tietenberg, 2000). Second, in Section 3, we turn to empirical evidence, namely the specific case of the Danish waste tax. Normally, it is not possible to trace actual bureaucratic behavior as it takes place in the dark and authors, so far, have not proven that actual bureaucratic rent-seeking has influenced political decision-making (see Tullock, 1967; Mueller, 1989 and Niskanen, 1994).

What furthermore characterizes an environmental bureaucracy is that they do not need organization to promote their interests. Due to their function, environmental bureaucrats will be involved in designing both national and international policies, and hence can promote their interests at all levels. This also means that it is hard to determine the influence of environmental bureaucracy as it does not rent-seek openly (Boom and Svendsen 2000, JITE).

Overall, we argue that strong fiscal pressure is strengthened by bureaucratic rent-seeking. Thus, we name this behavior 'bureaucratic tax-seeking' in the context of our troop leader and common-pool resource models. Environmental economists have in general paid no, or at best very little, attention to this bureaucratic context within which green taxation is to be introduced. So, to understand the reallife politics of green taxation and to base future policy recommendations on this analysis, one must identify the bureaucratic interests which determine the actual design of green taxes. In other words, our contribution is to fill the gap between theory and reality by revealing the bureaucratic constraints which determine the actual design of green tax schemes and to suggest a policy recommendation that deals with this economic distortion. 


\section{2: Bureaucratic Tax-Seeking}

As we saw in Figure 1, green tax revenues constitutes, by now, a significant part of total tax revenues in OECD countries. This taxation is a result of the government budget process. The budget process describes how decisions concerning public resources are made: It is the answer to the question, who does what, when, and how in the preparation and the implementation of the budget. The budget process is governed by formal and informal rules of behavior and interaction. ${ }^{3}$

Our argument is that this budget process leads to over-taxation and an irrational outcome for both bureaucrats and society as a whole. In the following, we will explain why by developing two theoretical models, namely the 'troop-leader model' (Section 2.1) and the 'common-pool resource model' (Section 2.2). The single-minded focus on fiscal purposes may finally lead to green taxation designs that are unavoidable to agents (Section 2.3).

\section{1: The Troop Leader}

Von Hagen and Harden (1995) formulate a model in which the overall government interest to meet the policy targets of all activities and to keep the social excess burden of taxation small leads to a government utility function. As borrowing is not possible the government optimal budget and the taxation is derived from this utility function.

As the government consists of a number of spending ministers the budget process is carried out by politicians characterized each of them by incentives different from obtaining the optimal budget seen from the collective government point of view. While spending minister has an interest to reach the policy target of his activity, each spending minister also receives a private utility gain from the size of

\footnotetext{
${ }^{3}$ Von Hagen and Harden (1995), p.772.
} 
his allocation, reflecting the political support of his constituency in response to greater benefits and, possibly, the prestige from commanding over larger resources. Furthermore each spending minister takes into account only a share of the burden of taxation that falls on his constituency. As a consequence the resulting budget from a budget process with spending ministers being able to manifest individual interests will be larger than the government optimal budget. The budget exhibits a spending bias because of each spending ministers extra utility from spending and because that the spending ministers neglect the externality the budget constraint imposes on all others if the spending ministers allocation is increased.

In von Hagens and Hardens model the spending bias can be reduced by strengthening the collective interest of the government. They introduce one or several ministers without portfolio - typically the minister of finance - not bound by the particular interests of a spending department and equipped with special strategic powers in the budget process as the power to set binding limits for the departmental allocations. Von Hagen and Harden show that the existence of the minister without portfolio partly overcomes the externality problem as such a minister presents a more integrating view of the budget. Raising the strategic power of the minister without portfolio reduces the impact the individual gains from spending has on the budget.

In Denmark the Ministry of Finance has taken up a still stronger position as coordinator of the general economic policy. ${ }^{4}$ This implies that this ministry has conquered a still stronger ability to ensure a result from the budget process close to the collective optimum. The ability to hold such a position as coordinator in the budget process depends on the traditional economic policy logic of taxation. Two basic assumptions in the von Hagen Harder model are that taxes are caused by the need of public revenue and that taxes are reducing social welfare. However, the economic policy logic of real-world green taxation differs from this ideal world of having one troop leader making the right overall budget decisions due to bureaucratic tax seeking for two reasons.

\footnotetext{
${ }^{4}$ Christensen (2000), p- 88-89.
} 
First, asymmetric information plays a crucial role. The problem is that the troop leader does not have sufficient information to control individual ministries and their activities concerning environmental tax revenues and their use. Such a task is most complex and asymmetric information therefore allows individual ministries to pursue private interests and budget-maximize.

Second, externalities may be promoted as new ideologies. Anne O. Krueger (1997) derives some universal learning about dangers in converting economic theory into legitimacy of economic policy from her years in the World Bank. She finds that a main problem in this converting process is misapplication of Good Theory. If (in principle good) economic theory is non-operational of nature or if the stylized facts are ignored, it opens for the establishing of a policy consensus taking form of an ideology conflicting with social efficiency.

Developing green taxation into being an ideology furthermore allows the spending ministry to keep the revenue for its own budget. This leaves the spending ministry free to use these revenues for employing more people. By creating more jobs for itself, it maximizes budgets and strategically consolidates its position by reducing the risk of not surviving potential future budget cuts. Already Dich (1973) has in a Danish context shown that welfare economics and externalities constitute such Good Theory which on the other hand is non-operational by nature. Thereby it allows the bureaucracy to construct an ideology dictating public growth. Once such ideology has been established, stylized facts are ignored. During a longer period since Dich the public growth has been strong. The overall tax level has reached a very high level and the capacity of taxation in the economy has become a dominant public growth restraint.

\section{2: Common-Pool Resource}

If an environmental bureaucracy is left more or less on its own, it is free to strive for the maximization of its budgets. An economically rational bureaucracy will maximize budgets because it can grow 
stronger by creating more jobs and resources for itself. This pursuing of bureaucratic goals rather than those of the general public is possible due to its monopoly power (Mueller, 1989). This is the reason why government budgets have become too large and should be reduced, Niskanen (1994).

Now, the general idea is that bureaucratic tax-seeking affects the design of green taxation in favor of bureaucracy and drives it too far compared to the optimal point. More specifically, we suggest that strong fiscal pressure occurs because bureaucracies are competing about resources just like fishermen or hunters. Taxing is like fishing or hunting.

Bureaucracies compete about maximizing their share of tax payers' money. This leads to an irrational outcome. Why? Because competition means 'over-taxing.' Taxing citizens and industry is a freeaccess resource (or 'common-pool resource'). It is not a pure public good because it only fulfills the first condition of non-exclusivity (where everyone can exploit the resource). The second condition of non-divisibility (where consumption does not change the good) is not fulfilled. ${ }^{1}$ Because the capture must be subtracted from the amount available to other bureaucracies, taxing is not a true public good but a semi-public good, i.e. a private good with open access. Therefore, the first-come, first-served principle applies; no individual or group hold power (or it does not pay) to restrict access. Consequently, we argue, overtaxing occurs, also leading to some green taxation against industry but without significant environmental effects in total.

As shown in Figure 2, benefits and costs from taxation can be viewed as a function of taxation efforts.

\footnotetext{
${ }^{1}$ Other well-known examples of such $\square$ open-access-ressources $\square$, the socalled $\square$ tragedy of the commons $\square$ (Hardin, 1968), are the rainforest, common grazelands and bison hunting.
} 
Figure 2: Green taxation as a common-pool resource.

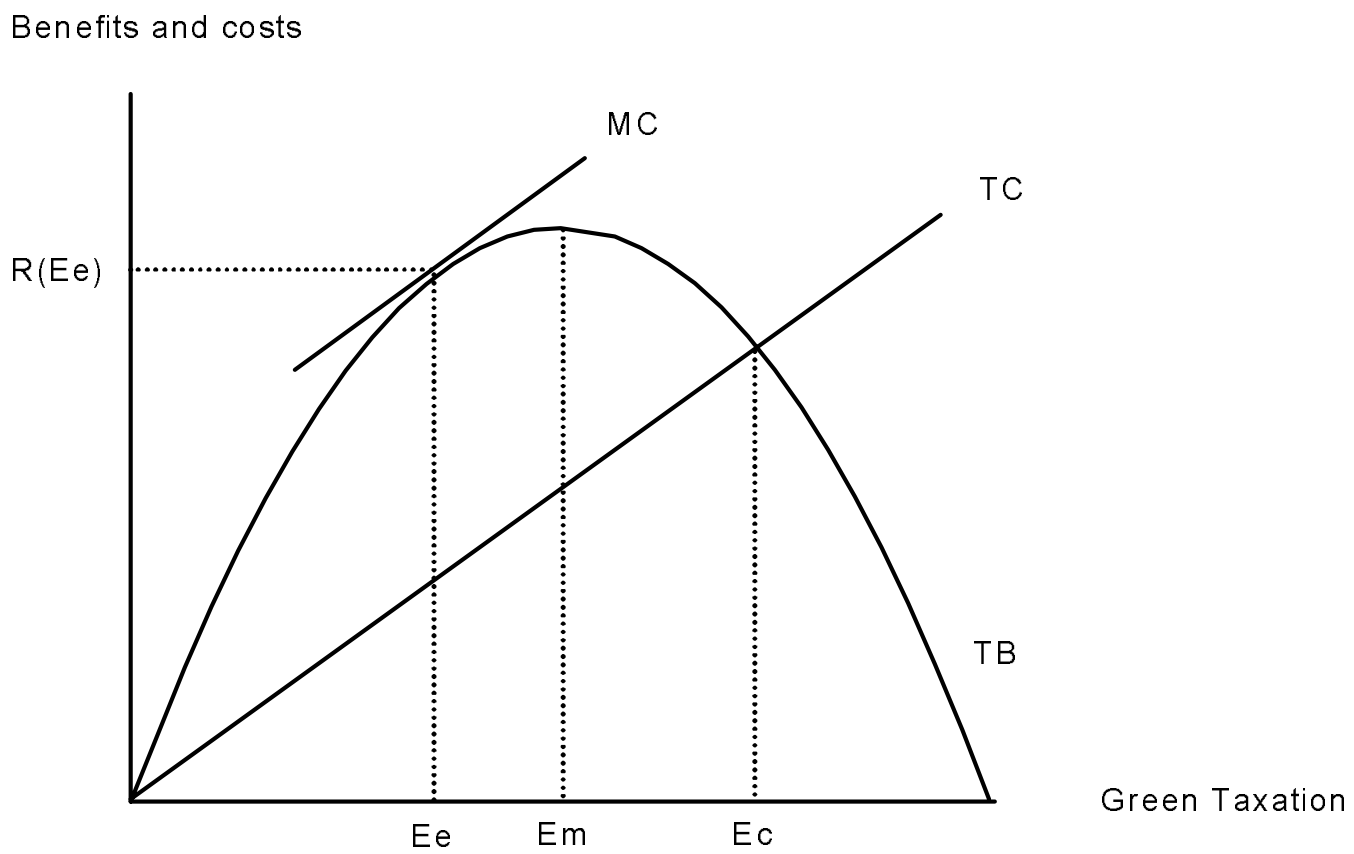

Source: Based on Tietenberg $(2000,284)$

The total benefit curve (TB) shows the annual tax revenue following green taxation (waste taxation in this specific setting). Even though the environmental bureaucracy does not get the tax revenue directly (it is typically collected by the Ministry of Taxation using already existing administrative infrastructure for doing so), the money will typically be recycled to the environmental bureaucracy (as happened e.g. in the Danish case) for environmental investments, earmarking, monitoring, enforcement, approval procedures etc. So, eventually, the tax revenue returns as more jobs and higher budgets for the environmental bureaucracy and may, as such, be perceived as shown in the TB curve above. 
Total costs (TC) shows the bureaucratic costs of taxing. The TC curve in this setting is different from the case of a fisherman spending equipment and time to get his catch. Bureaucracies which invest in increased tax collections benefit themselves from it as they hire more people to do so. Therefore, the TC curve described here assumes that the budget is fixed so that resources spent for inventing and implementing further tax collections must be found somewhere else within that same bureaucracy. Also, the TC curve may include political costs in the sense that too aggressive behavior may lead to political awareness and future budget cuts. This political risk following tax-seeking may be taken into account too.

Net benefits from green taxation are derived as the difference (vertical distance) between TB and TC. This vertical distance between TB and TC is maximized at taxation effort $\mathrm{E}^{\mathrm{e}}$. This is the efficient level where marginal benefits (MB) is equal to marginal costs (MC). $\mathrm{MB}$ is represented as the slope of the $\mathrm{TB}$ curve and the MC tangent represents the slope of the TC curve.

Because access to taxation is basically unrestricted (non-exclusive), an increasing number of bureaucracies will expand taxing effort beyond $\mathrm{E}^{\mathrm{e}}$. Why does overtaxing occur? It occurs because each bureaucracy has an incentive to increase taxing efforts until profits are zero, that is to $\mathrm{E}^{\mathrm{c}}$ in Figure 2. At this point, total revenue from green taxation is reduced and total costs increased compared to the optimal level, $\mathrm{E}^{\mathrm{e}}$.

Just like the individual fisherman trying to catch as much fish as possible, each bureaucracy will try to 'harvest 'as many tax revenues as possible per year. Even though extra green taxation reduces the population of production factors (e.g. industries may shut down or move abroad), the individual bureaucracy gets all the benefits and bears only a small share of the costs. By this, overtaxing will occur. Reversibly, it does not pay the single bureaucracy to reduce taxes. If one bureaucracy reduces taxation on its own, the benefits are mainly captured by others that do not restrain their behavior. Just like the individual fisherman that creates a larger catch for all the other fishermen by fishing less.

In perspective, bureaucratic tax-seeking will or affect the design of green taxation in favor of fiscal purposes. This drives the total level of taxation too far. According to economic theory, the state will maximize its total tax revenue by reaching the top point on the Laffer curve, where the product of the tax rate and national income is maximized. However, our logic of bureaucratic tax-seeking leads 
eventually to a situation where total tax level in society is situated to the right of the optimal tax rate.

Note, that it is not the single employee in an environmental bureaucracy that drives green taxation too far. It is the professional staff of lobbyists which has been hired to represent the interests of that very institution. Because the issue is one of institutions and impersonal mechanisms, interests are viewed as being promoted in an anonymous way such as negotiations among politicians and representatives for bureaucracies. In this way, the incentive to maximize environmental budgets derives from impersonal negotiations at the institutional level, Svendsen (1998).

In summary, bureaucracies will reap more than what is efficient to maintain the efficient amount of production factors. These uncoordinated activities reduce the stock of production thereby lowering future economic growth rates. Therefore, it is important that bureaucracies coordinate their taxing efforts, e.g. by avoiding the use of green taxes in relation to well-organized industries. If not, bureaucracies as a whole will reduce their future tax revenues (following the drop in production), that is, as the saying goes, 'shoot oneself in ones' own foot.'

\subsection{The Problem of Equivalence}

The theorem of Ricardian Equivalence states, that deficit finance is no different from current taxation, since individuals fully take into account the future taxes they will have to pay (Blanchard and Fischer, 1989, p. 129). The core point in this theorem is that public spending definitely has to be covered by public revenue when seen over a longer period, and that the individuals understand this simple logic. The original argument behind green taxation is the allocation effect, but when a fiscal function in reality becomes the dominant rationality of green taxation, a new type of equivalence problem can arise.

Normally the revenue from green taxation will be specified in the public budget and the agents in the economy will realize, that this revenue is necessary for balancing the economy. This means that reactions from the responsible spending ministry are to be expected if changed behavior among the 
agents in the economy results in a reduced revenue from the green taxes. Such reactions are especially to be expected if the revenue from a green tax is dedicated to financing activities in the spending ministry. If the agents in the economy realize that the revenue from a green tax is fixed due to fiscal purposes, the agents cannot free themselves from the burden of the tax even when changing behavior and reducing the tax releasing behavior. Overall, we are left with a zero sum game where the likely outcome is the abolition of the link between green taxation and the behavior of the agents in the economy.

\section{3: The Danish Waste Tax}

A waste tax was introduced in a modest form in Denmark in $1987 .{ }^{2}$ The tax was collected as a duty tax after weight imposed on all waste covered by a compulsory deliveries regulation.

The Danish waste tax became soon raised substantially. The higher tax level was introduced in 1990 with a revision of the 1987 law. ${ }^{3}$ In the comments to the law proposal the responsible minister of the environment formulated an argumentation for raising the level of waste taxation. ${ }^{4}$ The argumentation is (translation from Danish by the authors): 'The background (for raising the tax level) is among other things an expected growth at around 50 pct. in the amounts of waste in the period until the beginning of the next millenium. Thus, a further strengthening of the effort to increase recirculation is needed.'

When presenting the law proposal, the minister of the environment pointed out, that an ongoing improvement of the technique in Danish refuse disposal plants would possibly change the need of economic incentives within the next 2 to 3 years, and that the ministry then would present a report analyzing this problem. When preparing the latter, the ministry of the environment initiated a research

\footnotetext{
${ }^{2}$ Law concerning alteration of law on protection of the environment. Law number 329. June 4. 1986.

${ }^{3}$ Law on tax on waste and raw materials. Law number 838. June 6. 1989.

${ }^{4}$ Proposal for Law on tax on waste and raw materials. Proposal number LSF 100. December 7. 1989.
} 
project on the effects of the waste tax. This research project resulted in Christoffersen, Hansen, Hansen and Kriegbaum (1992). They characterized the effects from the waste tax on the incentives in the waste production and treatment system. These effects within the three largest segments of waste production covering about $70 \%$ of total ordinary waste production are summed up in Table 2 .

Table 2. Effects from the waste tax on the incentives in the waste production and treatment system. The three largest waste segments.

\begin{tabular}{|l|l|}
\hline Household waste & $\begin{array}{l}\text { All households are obliged to hold and to pay a fixed price for a garbage can. The } \\
\text { local municipality is responsible for managing the waste collection and for paying } \\
\text { waste tax. By charging a fixed price per year not weighting the production of waste } \\
\text { in the individual household, the households are not allowed to free themselves from } \\
\text { the burden of the tax. The municipalities are obliged to separate the economy in the } \\
\text { waste collection task from the municipal economy as a whole, so reduction of } \\
\text { household waste production does not improve the economy of the individual } \\
\text { municipality. }\end{array}$ \\
\hline $\begin{array}{l}\text { Industry waste. Not including } \\
\text { environmentally problematic } \\
\text { waste }\end{array}$ & $\begin{array}{l}\text { Reduction of waste production or increase of recirculation is complicated and costly } \\
\text { to implement. The size of the waste tax is small compared with this. Experiences } \\
\text { documented in empirical studies seem to show that changed performance in waste } \\
\text { treatment in industrial companies can mainly be explained by a combination of } \\
\text { offering consultancy services to the companies and using bureaucratic regulation. } \\
\text { The waste tax seems to be of only a minor importance. }\end{array}$ \\
\hline Construction sector waste & $\begin{array}{l}\text { Important recirculation possibilities, but dependent upon the presence of plants for } \\
\text { treatment and manufacturing of materials usable in new production processes. } \\
\text { Experiences documented in empirical studies seem to show that changed } \\
\text { performance in waste treatment in construction companies can also be explained by } \\
\text { the municipal use of bureaucratic regulation, whereas the effects of the waste tax } \\
\text { seem to rather small. }\end{array}$ \\
\hline
\end{tabular}

Source: Based on Christoffersen, Hansen, Hansen and Kriegbaum (1992)

When confronting the argumentation behind the waste tax with these effects, emphasis should be laid on two questions as seen in Table 3. The first question concerns the existence of a link between the size of the waste tax and the behavior of the waste producers. Such a link exist only if the waste producers are able to free themselves from the tax by changing behavior. The second question concerns the existence of alternatives in persecuting the purpose of influencing the behavior of the waste producers. The waste tax is a convenient instrument only if there does not exist other 
instruments characterized by obtaining the desirable effects at lowest costs.

Table 3. The social efficiency of the Danish waste tax

\begin{tabular}{|l|l|l|}
\hline & $\begin{array}{l}\text { Is the waste producer allowed to } \\
\text { free himself from the burden of } \\
\text { the tax? }\end{array}$ & $\begin{array}{l}\text { Does there exist means } \\
\text { characterized by stronger desired } \\
\text { effects obtained at an expense of } \\
\text { smaller costs? }\end{array}$ \\
\hline Household waste & $\begin{array}{c}\text { No. Not as long as the municipalities } \\
\text { are charging a fixed price }\end{array}$ & $\begin{array}{l}* \text { Charging waste tax variably by } \\
\text { weight } \\
* \text { Regulating the waste potential in } \\
\text { household consumption }\end{array}$ \\
\hline $\begin{array}{l}\text { Industry waste. Not including } \\
\text { environmentally problematic waste }\end{array}$ & $\begin{array}{r}\text { Yes, but complicated } \\
\text { (Consultancy support to industries } \\
* \text { Administrative regulation } \\
* \text { Voluntary agreements with } \\
\text { industries }\end{array}$ \\
\hline $\begin{array}{l}\text { Construction sector waste } \\
\text { Yes, if relevant public facilities are } \\
\text { at disposal }\end{array}$ & $\begin{array}{l}* \text { Establishing recirculation facilities } \\
* \text { Administrative regulation } \\
* \text { Voluntary agreements with } \\
\text { companies }\end{array}$ \\
\hline
\end{tabular}

Source: Based on Christoffersen, Hansen, Hansen and Kriegbaum (1992)

The conclusions which can be drawn from Table 3 seems to be that it is more than doubtful whether the waste tax represents an optimal choice of solution to the problem defined in the official argumentation behind the legislation.

The legal lines of direction concerning the use of the revenue from the waste tax are defines in the official comments from the minister on the original law proposal from 1986 introducing the waste tax. ${ }^{5}$ These comments states that 'On the approved budget for 1986 an account is established under the ministry of the environment concerning the revenue from taxes and fees within the waste sector. The revenue is presupposed used to financing the solution of waste problems and to encourage reduction of waste production and increasing recirculation and with that environmental improvements

\footnotetext{
${ }^{5}$ Proposal for law changing law on environmental protection. Proposal number LSF 176. 1986.
} 
in a broad sense' (translation from Danish by the authors).

These premises for the use of the waste tax revenue constitute together with the argumentation for the waste tax the factors defining the political logic of the waste tax: The waste tax is not caused by the need in general of public revenue but by the need of adjusting the resource allocation in the economy. In doing so the waste tax is increasing social welfare.

The design of the waste tax constitutes an incentive for the minister of the environment and for the bureaucracy in this ministry to ensure a large revenue from the tax. As the level of the tax is controlled by the parliament the ability of the ministry to influence the revenue consists mainly in letting the waste reducing effect of the tax be small and by avoiding the use of other means having a stronger effect.

Because of this the ministry of the environment has a strong incentive to disseminate two ideas. First, the idea of a threat against society from the waste production. Second, the idea that the appropriate instrument to challenge this threat is green taxation. General approval of these ideas is needed to ensure the continuation of the tax and to ensure autonomy in relation to the ministry of finance as the overall budget coordinator (the 'troop leader'). These ideas refers to Good Theory and according to Anne Krueger they open for misapplication and the establishing of a policy consensus taking form of an ideology if they are non-operational of nature or if the stylized fact are ignored.

When the ministry of the environment in 1992 received the research rapport which the ministry itself has initiated (Christoffersen, Hansen, Hansen and Kriegbaum (1992)), the ministry locked it up. The results therefore did not reach the Parliament before reading the proposal for raising the tax level substantially. 


\section{4: Conclusion}

Our starting point was the two main results in traditional tax theory. First, that general taxes minimized the welfare loss from changed relative prices. Second, because the total public budget tended to exceed the optimal size, a leader (here named 'troop leader') was needed in the budget process to prevent over-taxation.

Nevertheless, differentiated taxes initiated by individual ministries generate a still larger proportion of total tax revenue, in particular under cover of taxing externalities such as environmental pollution. We suggested that this situation led to over-taxation for two reasons. First, the absence of a strong and fully informed troop leader prevented rational coordination of collective action. Second, budget maximization led to overwhelming fiscal pressure because bureaucracies were competing about resources just like fishermen or hunters (here named 'bureaucratic tax-seeking'). Taxing citizens or firms was arguably like harvesting rents from a natural resource and therefore we applied a commonpool resource model. Because bureaucracies competed about maximizing their share of tax payers $\square$ money, this led to over-taxation and an irrational outcome for both bureaucrats and society. These theoretical propositions were strongly confirmed by the case of the Danish waste tax.

Thus, we recommend that bureaucratic institutions should coordinate their tax-seeking efforts to maximize budgets in the long run and that the ministries that collect green tax revenues should not be allowed to control these revenues. Such a budget maximization opportunity would kick off a new self-destructive fiscal race among competing tax-seeking bureaucracies. 


\section{References}

Blanchard, Olivier Jean and Stanley Fischer (1989): Lectures on Macroeconomics. MIT Press.

Bohm, Peter (1987): Social efficiency. A concise introduction to welfare economics. Second edition. Macmillan.

Boom, J. and Svendsen, G.T. (2000): 'International Emission Trading Systems: Trade Level and Political Acceptability. 'JITE (Journal of Instititutional and Theoretical Economics). Forthcoming.

Christensen, Jørgen Grønnegaard (2000): Efter almindelige administrative principper: Efterkrigstidens centraladministration. In Peter Bogason, ed. Dansk Forvaltningshistorie. Stat, forvaltning og samfund efter 1950. Jurist- og Økonomforbundets Forlag.

Christoffersen, Henrik, Henning Hansen, Lars Gårn Hansen and Lene Kriegbaum (1992): Affaldsafgiftens effekter. Manuscript in Institute of Local Government Studies, Denmark.

Daugbjerg, C. and Svendsen, G.T. (2001): Green Taxation in Question MacMillan. Forthcoming.

Dich, Jørgen S. (1973): Den herskende klasse. En kritisk analyse af social udbytning og midlerne imod den. Borgen.

Hagen, Jürgen von and Ian J. Harden (1995): Budget processes and commitment to fiscal discipline. European Economic Review, 39, p 771-779.

Hardin, G. (1968), The Tragedy of the Commons, Science, 162, pp. 1243-48.

Howe, C.W. (1994), 'Taxes Versus Tradable Discharge Permits: A Review in the Light of the U.S. and European Experience', Environmental and Resource Economics, 4, 151-69. 
Krueger, Anne O. (1997): Trade policy and economic development: How We Learn. The American Economic Review. Volume 87,1, p 1-22.

Mueller, D.C. (1989), Public Choice II, Cambridge: Cambridge University Press.

Niskanen, W.A. Jr. (1994), Bureaucracy and Public Economics. The Locke Institute, Cheltenham: Edward Elgar.

OECD (2000) : DATABASE ON ENVIRONMENTALLY RELATED TAXES http://www.oecd.org/env/policies/taxes (date of access: November 8, 2000).

Pigou, A.C. (1932 [1920]), The Economics of Welfare. London: Macmillan and Co.

Svendsen, G.T. (1998): Public Choice and Environmental Regulation: Tradable Permit Systems in United States and $\mathrm{CO}_{2}$ Taxation in Europe. New Horizons in Environmental Economics, Edward Elgar, Cheltenham, UK.

Tietenberg, T.H. (2000), Environmental and Natural Resource Economics, Fifth Edition, Harper Collins College Publishers.

Tullock, G. (1967), The Welfare Costs of Tariffs, Monopolies, and Theft. Western Economic Journal, 5, 224-32. 